\title{
In vivo metabolism of alpha-tocopherol in lipoproteins and liver: studies on rabbits in response to acute cholesterol loading
}

\author{
Department of Molecular \& Cell Biology, University of Aberdeen, Scotland \\ Cardiovascular Research Unit, University of Edinburgh, Scotland
}

\begin{abstract}
Objective: To investigate the transport of alpha-tocopherol in lipoproteins of rabbits under normal diet and under acute loading of cholesterol. Design: Two New Zealand White rabbits were fed ${ }^{14} \mathrm{C}$-alpha-tocopherol acetate in a single oral dose and the recovery of radiolabel in lipoproteins and plasma was monitored. Low density lipoprotein (LDL) from these animals was obtained and labeled with $\left[{ }^{3} \mathrm{H}\right]$ cholesteryl ester. Three other rabbits were injected with this double-labeled LDL in the native form; while three other animals received this LDL in the acetylated form. Results: Plasma clearance, liver uptake and levels of radiolabel in high density lipoprotein (HDL) of animals injected with ${ }^{14} \mathrm{C}\left[{ }^{3} \mathrm{H}\right]$ acetyl LDL were significantly higher than those in animals injected with ${ }^{14} \mathrm{C}\left[{ }^{3} \mathrm{H}\right]$ native LDL. Larger particles of HDL, rich in apolipoprotein $\mathrm{E}$ (apoE) carried significantly higher levels of both labels in rabbits injected with acetylated LDL. Conclusion: These results provide evidence for in vivo mechanisms of "reverse alpha-tocopherol transport", analogous to "reverse cholesterol transport".
\end{abstract}

Uniterms: Atherosclerosis. Alpha-tocopherol. HDL.

\section{INTRODUCTION}

$\mathrm{H}$ igh density lipoprotein (HDL) is considered to be a protective factor against coronary heart disease (CHD), as shown in several clinical trials ${ }^{1}$ One antiatherogenic effect of HDL has been attributed to its ability to remove surplus cholesterol from peripheral tissues and transport it to the liver for excretion or reutilization, in a process known as "reverse cholesterol transport". ${ }^{2,3}$ The larger particles of HDL, rich in apolipoprotein E (apoE), have been demonstrated to be

\author{
Present address for correspondence: \\ Yara Dadalti Fragoso \\ Departamento de Clínica Médica \\ Faculdade de Ciências Médicas de Santos \\ Rua Oswaldo Cruz, 179 \\ Santos/SP - Brasil CEP 11045-101 \\ e-mail:yara@bsnet.com.br
}

significantly decreased in patients with CHD when compared to matched healthy controls. ${ }^{4-6}$ In an analogous manner to reverse cholesterol transport, HDL may serve to transport alpha-tocopherol from peripheral tissues to the liver. ${ }^{7}$ The antioxidative activity of alpha-tocopherol has received particular attention in recent years, since oxidative modification of low density lipoprotein (LDL) may be a critical step in atherogenesis..$^{8-11}$ Epidemiological studies have shown conflicting results in the correlation of plasma levels of alpha-tocopherol and coronary risk, ${ }^{12-18}$ and there have been no reports on the distribution of alphatocopherol in subfractions of HDL in response to acute cholesterol loading. We have recently reported on the distribution of alpha-tocopherols and carotenes in subfractions of HDL separated according to their apoE contents. ${ }^{19}$ Subfractions of HDL may be a more reliable index for evaluation of coronary risk rather than total levels of plasma HDL, since such subfractions comprise a variety of particles with different physico-chemical characteristics. ${ }^{20}$ In our report, ${ }^{19}$ plasma levels of HDL- 
cholesterol were highly correlated with the relative proportions of alpha-tocopherol in apoE-rich HDL, while the main carrier of alpha-tocopherol in HDL was an apoEpoor HDL subfraction. The aim of the present study was to help to elucidate the mechanisms underlying these observations. The New Zealand White rabbit was chosen as an animal model, since its plasma lipids and lipoproteins profile is similar to that of humans ${ }^{21}$ and its alphatocopherol distribution in HDL subfractions is akin to the human counterparts. ${ }^{19}$ Subfractions of HDL in this strain of rabbits were shown to be similar to that of humans, and to be highly sensitive to acute cholesterol loading. ${ }^{22,23}$ The progression of atherosclerotic lesions of rabbit arteries can be inhibited by antioxidants in vivo. ${ }^{11}$

\section{METHODS}

\section{Animals}

New Zealand White rabbits aged 6-10 months were studied. They were caged individually, in a room with controlled temperature $\left(20^{\circ} \mathrm{C}\right)$ and cycled with $12 \mathrm{hrs} \mathrm{light/}$ darkness. The animals had continuous access to standard laboratory chow (Rabbit maintenance R14) containing $6,000 \mathrm{iu} / \mathrm{kg}$ of beta-carotene from $20,000 \mathrm{iu} / \mathrm{kg}$ of vitamin $\mathrm{A}$, and $73 \mathrm{iu} / \mathrm{kg}$ vitamin $\mathrm{E}$ as alpha-tocopherol. The daily intake of chow was of the order of $100-130 \mathrm{~g} /$ rabbit. Water

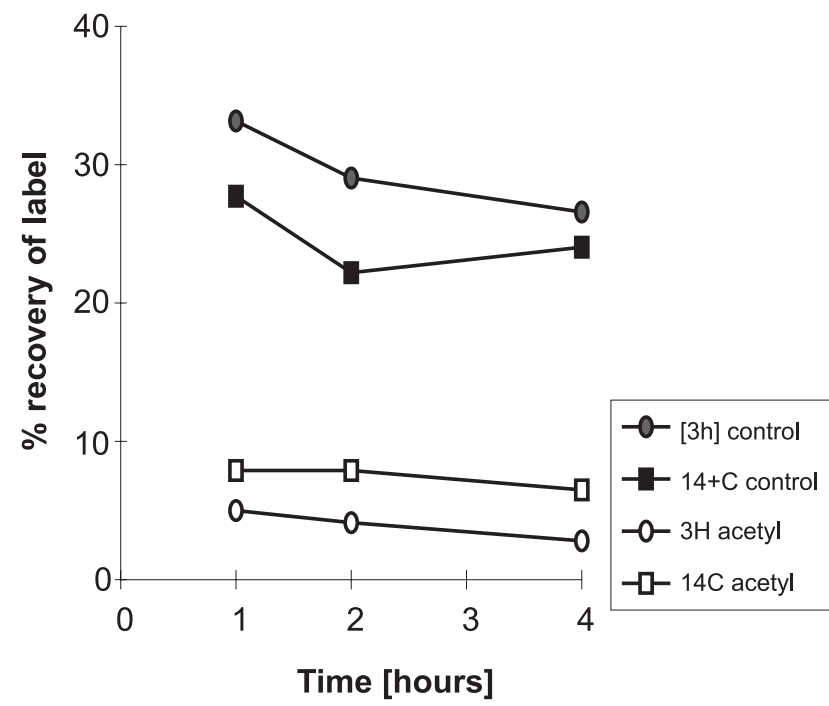

Figure 1 - Plasma levels of $\left[{ }^{3} \mathrm{H}\right]$ cholesteryl linoleate and ${ }^{14} \mathrm{C}$-alphatocopherol injected with LDL into two groups of rabbits. One group $(n=3)$ received native LDL (controls) and the other group $(n=3)$ received acetyl LDL (cholesterol-loaded animals). Standard deviation (SD) is shown in error bars. was also available ad libitum. At the end of each study, the animals were given an overdose of Sagatal (pentobarbitone sodium, BP) by injection into the marginal ear vein. During deep anesthesia, blood was collected by cardiac puncture into a vial containing ethylenediaminetetraacetate (EDTA) $(1.5 \mathrm{mg} / \mathrm{ml})$, and the vial was immediately placed on ice. After death was confirmed, the abdomen and thorax were opened for delicate washing of the liver ex vivo followed by removal of liver and aorta, which were placed in cold ice saline. The gall bladder was punctured and bile was collected into a separate vial.

\section{Plasma and lipoproteins}

Plasma and lipoproteins were isolated as previously described. ${ }^{22-24}$ All procedures were carried out at low temperature and in the presence of $1 \mathrm{mM}$ EDTA, and samples were kept under a stream of $\mathrm{N}_{2}$.

\section{Heparin-Sepharose affinity chromatography}

Separation of apoE-poor and apoE-rich HDL was performed by affinity chromatography in a $15 \times 1 \mathrm{~cm}$ glass column containing heparin coupled to activated Sepharose as previously described. ${ }^{25,26}$ During affinity chro-

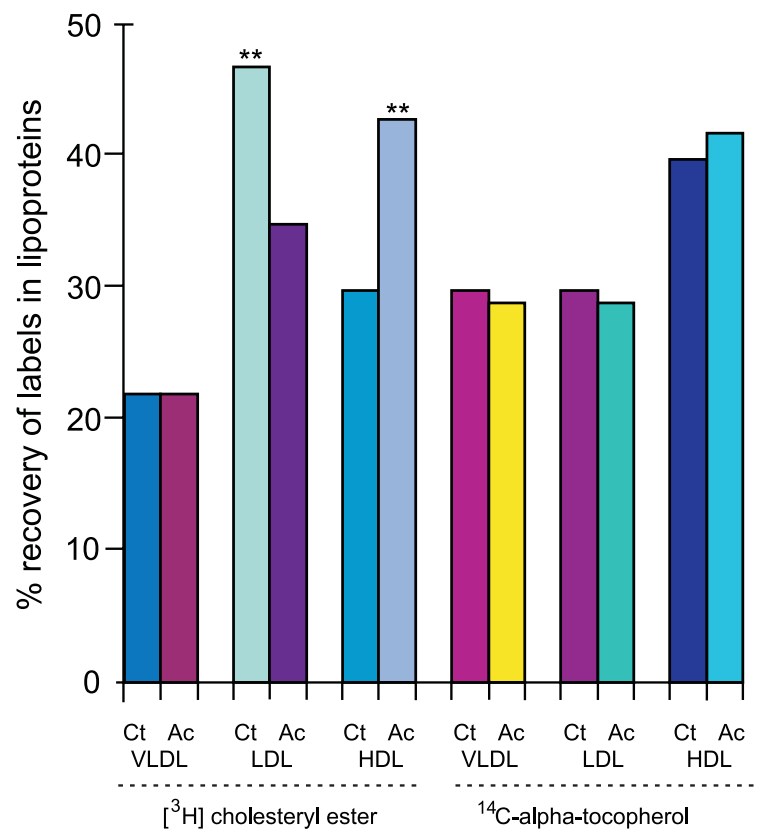

Figure 2 - Recovery of radiolabels in lipoproteins of rabbits $4 \mathrm{hrs}$ after injection of ${ }^{14} \mathrm{C} /\left[{ }^{3} \mathrm{H}\right] \mathrm{LDL}$.

The two groups of animals are as for Fig 1.

$\mathrm{Ct}=$ control rabbits, $\mathrm{Ac}=$ rabbits injected acetyl-LDL

Total label recovered in lipoproteins was considered as $100 \%$. Recovery of labels in infranatant $(\mathrm{d}>1.25 \mathrm{~g} / \mathrm{ml})$ was negligible.

Results are presented as mean value \pm SD.

${ }^{* *} \mathrm{P}<0.01$ in relation to controls. 
matography, EDTA was omitted, but all buffers were degassed and kept under a stream of $\mathrm{N}_{2}$. Subfractions of HDL thus isolated (apoE-poor and apoE-rich HDL) were immediately dialyzed against $50 \mathrm{mM} \mathrm{NaCl}, 1 \mathrm{mM}$ EDTA, $5 \mathrm{mM}$ Tris- $\mathrm{HCl}, \mathrm{pH} 7.4$ and frozen under $\mathrm{N}_{2}$. Subfractions of HDL from all rabbits were freeze-dried and the contents taken up in hexane for radioactivity measurements. The relative percentage of subfractions of HDL was calculated from a summation of absorbance values $(280 \mathrm{~nm})$ of individually collected fractions. ${ }^{27}$

\section{In vivo studies in the rabbit}

Two rabbits were fed all-racemic ${ }^{14} \mathrm{C}$-alphatocopherol in a single dose, by orogastric tube. Each animal received $50 u \mathrm{Ci}(1.85 \mathrm{MBq}){ }^{14} \mathrm{C}-3,4$-alphatocopherol $(113 u \mathrm{Ci} / \mathrm{mg}, 0.99 \mathrm{mCi} / \mathrm{ml})$ dissolved in $2 \mathrm{ml}$ olive oil. No adverse reaction was observed in these animals. One rabbit was sacrificed after $24 \mathrm{hrs}$, the other after $48 \mathrm{hrs}$. LDL from these animals was isolated by ultracentrifugation, pooled, dialyzed against $150 \mathrm{mM}$ $\mathrm{NaCl}, 0.3 \mathrm{mM}$ EDTA, 5mM Tris- $\mathrm{HCl}, \mathrm{pH} 7.4$ and $[1,2$ $\left.{ }^{3} \mathrm{H}\right]$ cholesteryl linoleate was incorporated into the lipoprotein as previously described..$^{22,24}$ Half the sample was separated and described as " ${ }^{14} \mathrm{C} /\left[{ }^{3} \mathrm{H}\right]$ native LDL". The other half was dialyzed against $150 \mathrm{mM} \mathrm{NaCl}$, Tris-

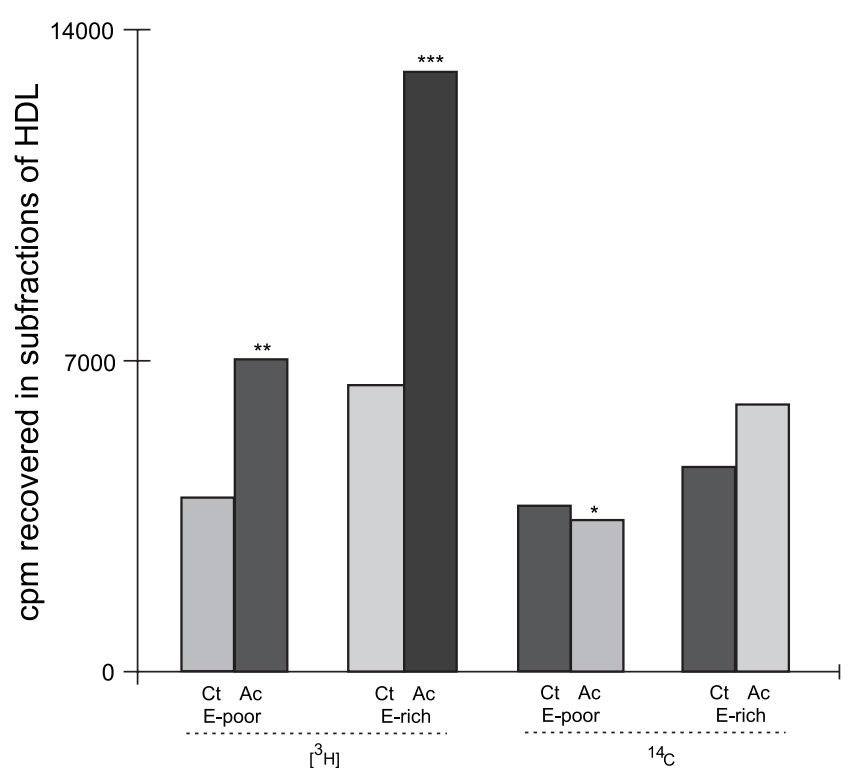

Figure 3 - Recovery of radiolabels in subfractions of HDL of rabbits injected with ${ }^{14} \mathrm{C} /\left[{ }^{3} \mathrm{H}\right] \mathrm{LDL}$.

The two groups of animals are as for Fig 1.

$\mathrm{Ct}=$ control rabbits, $\mathrm{Ac}=$ rabbits injected acetyl-LDL

Results are presented as mean value \pm SD.

${ }^{*} \mathrm{P}<0.05,{ }^{* *} \mathrm{P}<0.01,{ }^{* *} \mathrm{P}<0.001$ in relation to controls.
$\mathrm{HCl}, \mathrm{pH} 7.4$, submitted to chemical modification by acetylation, ${ }^{23,24,28}$ and described as ${ }^{~}{ }^{14} \mathrm{C} /\left[{ }^{3} \mathrm{H}\right]$ acetyl LDL".

The final samples of labeled LDL contained similar amounts of protein and radiolabels. Each animal entering this phase of the study received $1.2 \mathrm{mg}$ LDL protein, $0.45 \mathrm{mCi}$ of $\left[{ }^{3} \mathrm{H}\right]$, and $20 u \mathrm{Ci}$ of ${ }^{14} \mathrm{C}$ by injection on the right marginal ear vein. The final volume injected was $1.4 \mathrm{ml}$.

Two groups of New Zealand White rabbits matched for sex, age and weight ( $\mathrm{n}=3$ in each group) were injected with double-labeled LDL, and were sacrificed $4 \mathrm{hrs}$ later. One group received injections of " ${ }^{14} \mathrm{C} /\left[{ }^{3} \mathrm{H}\right]$ native LDL" and the other received " ${ }^{14} \mathrm{C} /\left[{ }^{3} \mathrm{H}\right]$ acetyl LDL". Small blood samples taken during this study were drawn from the left marginal ear vein. All procedures were carried out in the same day for both groups of animals.

\section{Radioactivity measurements}

Samples taken for measurement of radioactivity were dissolved in Optiphase hisafe-II (Pharmacia LKB). Duplicate samples were counted over 3min in an LKB 1219 Rackbeta counter, the data being processed by Ultroterm 2 , which was programmed to correct for quenching. The program was also specially set up for double-label counting. There was excess $\left[{ }^{3} \mathrm{H}\right]$ in all samples.

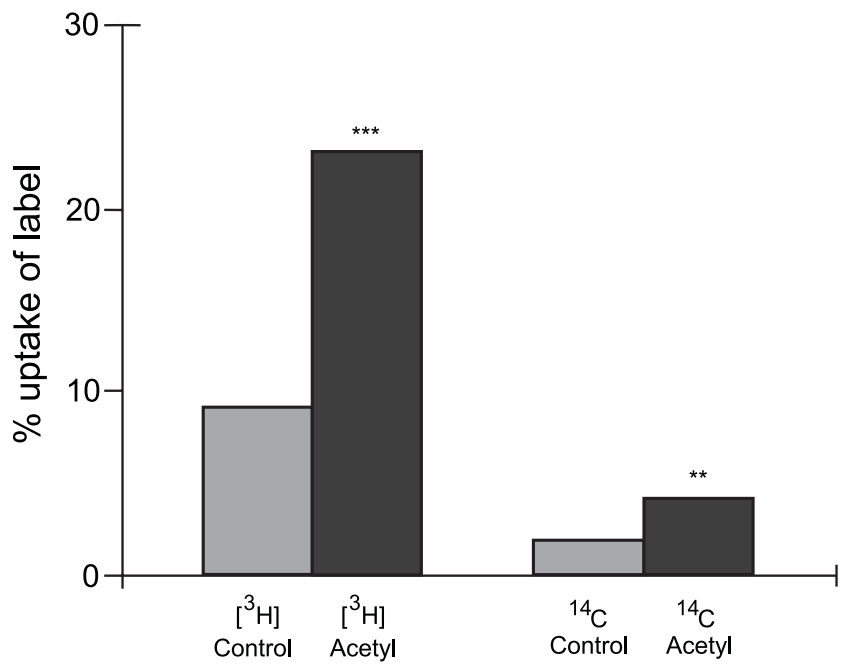

Figure 4 - Recovery of radiolabels in the liver of rabbits injected with ${ }^{14} \mathrm{C} /\left[{ }^{3} \mathrm{H}\right] \mathrm{LDL}$.

The two groups of animals are as for Fig 1.

$\mathrm{Ct}=$ control rabbits, $\mathrm{Ac}=$ rabbits injected acetyl-LDL

Results are presented as mean value \pm SD.

${ }^{\star *} \mathrm{P}<0.01,{ }^{* *} \mathrm{P}<0.001$ in relation to controls. 
Table 1

Percentage of recovery of ${ }^{14} \mathrm{C}$ in plasma, lipoproteins, subfractions of $\mathrm{HDL}$ and liver of two rabbits fed $50 \mathrm{CCi}$ $(1.85 \mathrm{MBq}){ }^{14} \mathrm{C}-3,4-a l p h a-t o c o p h e r o l ~(113 u \mathrm{Ci} / \mathrm{mg}, 0.99 \mathrm{mCi} / \mathrm{ml})$ dissolved in $2 \mathrm{ml}$ olive oil. Rabbit A was sacrificed after 24 hours, rabbit $B$ after $\mathbf{4 8}$ hours. Radioactivity recovered in lipoproteins was considered $100 \%,{ }^{14} \mathrm{C}$ in infranatant $(\mathrm{d}>1.25 \mathrm{~g} / \mathrm{ml})$ was negligible. Relative percentage of ${ }^{14} \mathrm{C}$ in subfractions of $\mathrm{HDL}$ were calculated in relation to total ${ }^{14} \mathrm{C}$ in HDL.

\begin{tabular}{|c|c|c|c|c|c|c|c|}
\hline & Plasma & VLDL & LDL & HDL & $\begin{array}{c}\text { apoE-poor } \\
\text { HDL }\end{array}$ & $\begin{array}{c}\text { apoE-rich } \\
\text { HDL }\end{array}$ & Liver \\
\hline Rabbit A & 31.0 & 76.7 & 16.3 & 7.0 & 21.1 & 78.9 & 2.4 \\
\hline Rabbit B & 14.5 & 65.8 & 22.2 & 12.0 & 49.1 & 50.9 & 3.2 \\
\hline
\end{tabular}

\section{RESULTS}

No adverse reactions were observed in any of the animals entering the present investigation.

Recovery of ${ }^{14} \mathrm{C}$ in plasma, subfractions of $\mathrm{HDL}$ and liver of the rabbits which were fed ${ }^{14} \mathrm{C}$ alpha-tocopherol is shown in Table 1. Plasma levels of ${ }^{14} \mathrm{C}$ were continuing to decrease at $48 \mathrm{hrs}$ after ingestion of the label and its transfer among lipoproteins was relatively slow in the rabbits. The newly ingested alpha-tocopherol appeared to have entered the HDL system via apoE-rich particles, and then distributed to apoE-poor HDL, although other pathways may be operative.

Levels of $\left[{ }^{3} \mathrm{H}\right]$ and ${ }^{14} \mathrm{C}$ in plasma of the two groups of animals receiving injections of LDL is summarized in Fig 1, and lipoprotein levels of radiolabels is shown in Fig. 2. Significantly lower levels of both radiolabels was observed in plasma of animals injected with ${ }^{14} \mathrm{C} /\left[{ }^{3} \mathrm{H}\right]$ acetyl LDL $(\mathrm{P}<0.01)$. Significantly higher levels of $\left[{ }^{3} \mathrm{H}\right]$ was present in LDL of animals injected with ${ }^{14} \mathrm{C} /\left[{ }^{3} \mathrm{H}\right]$ native LDL $(\mathrm{P}<0.01)$, while higher recovery of $\left[{ }^{3} \mathrm{H}\right]$ was observed in HDL of animals injected with ${ }^{14} \mathrm{C} /\left[{ }^{3} \mathrm{H}\right]$ acetyl LDL $(\mathrm{P}<0.01)$. The distribution of ${ }^{14} \mathrm{C}$-alpha-tocopherol was similar among all lipoproteins in both groups of animals (Fig. 2).

Although consistently higher, the relative proportions of ${ }^{14} \mathrm{C}$-alpha-tocopherol found in apoE-rich HDL in rabbits loaded with cholesterol were not statistically significant, even when calculated as ${ }^{14} \mathrm{C}$-alpha-tocopherol/ $\left[{ }^{3} \mathrm{H}\right]$ cholesteryl ester. The ratio ${ }^{14} \mathrm{C} /\left[{ }^{3} \mathrm{H}\right]$ in apoE-poor HDL is consistently higher for controls and should this trend persist with time, it would be in agreement with our previous finding for humans and rabbits. ${ }^{19}$ However, when radioactivity in total HDL was considered $100 \%$, apoEpoor HDL of treated animals contained more $\left[{ }^{3} \mathrm{H}\right]$ than that of controls $(\mathrm{P}<0.01)$. ApoE-rich $\mathrm{HDL}$ was highly enriched with $\left[{ }^{3} \mathrm{H}\right]$ in relation to controls $(\mathrm{P}<0.001)$. There were no differences between levels of ${ }^{14} \mathrm{C}$ in the apoE- poor HDL particles of both groups of animals, although a significantly higher level of ${ }^{14} \mathrm{C}$ was observed in apoErich $\mathrm{HDL}$ of treated animals $(\mathrm{P}<0.05)$ (Fig. 3).

Recovery of both labels in the aorta and bile of all rabbits was less than $0.5 \%$ and hence no meaningful comparisons can be made. Liver uptake of $\left[{ }^{3} \mathrm{H}\right]$ and ${ }^{14} \mathrm{C}$ showed a significant difference for both labels in the two groups (Fig. 4). Animals injected with ${ }^{14} \mathrm{C} /\left[{ }^{3} \mathrm{H}\right]$ acetyl LDL had higher levels of $\left[{ }^{3} \mathrm{H}\right](\mathrm{P}<0.001)$ and of ${ }^{14} \mathrm{C}(\mathrm{P}<0.01)$ than did the animals injected with ${ }^{14} \mathrm{C} /\left[{ }^{3} \mathrm{H}\right]$ native LDL. The ratio ${ }^{14} \mathrm{C} /\left[{ }^{3} \mathrm{H}\right]$ in the liver of both groups of animals was comparable, i.e. 0.20 for animals that received ${ }^{14} \mathrm{C} /$ $\left[{ }^{3} \mathrm{H}\right]$ native LDL and 0.18 for rabbits injected with ${ }^{14} \mathrm{C} /$ $\left[{ }^{3} \mathrm{H}\right]$ acetyl LDL.

\section{DISCUSSION}

It is generally accepted that both HDL and vitamin E can be antiatherogenic, albeit by different mechanisms of action. HDL appears to mediate the process of reverse cholesterol transport while vitamin E may protect lipids against oxidation. HDL carries approximately half of the total alpha-tocopherol in plasma ${ }^{19}$ and can protect LDL against oxidation, at least in vitro. ${ }^{29-31}$ However, HDL has yet to be clearly shown to participate in reverse cholesterol transport, ${ }^{3}$ and the occurrence of oxidized LDL in vivo is still contentious. ${ }^{8,32}$ Therefore, further investigations into the role of these antiatherogenic particles are needed in order to fully understand the pathophysiology of atherosclerosis and to have a means of altering the course of the disease..$^{33,34}$

With data provided by two rabbits fed ${ }^{14} \mathrm{C}$-alphatocopherol, it appears that, following an oral dose of vitamin $\mathrm{E}$, its transfer among lipoproteins of the rabbit is relatively slow, although such a finding may be due to the mixture of isomers used to feed the animals. Since RRR- 
alpha-tocopherol is preferentially incorporated into plasma lipoproteins, ${ }^{35}$ it is likely that the sample of ${ }^{14} \mathrm{C}$-LDL obtained from the donor animals contained mostly the naturally occurring isomer.

When rabbits were injected with LDL containing ${ }^{14} \mathrm{C}$ alpha-tocopherol, equilibration of the label in the different pools of lipoproteins occurred faster than when animals were fed the labeled alpha-tocopherol. Although the distribution of ${ }^{14} \mathrm{C}$-alpha-tocopherol among the lipoproteins was similar in both groups of rabbits injected with labeled LDL, plasma clearance of ${ }^{14} \mathrm{C}$ was faster in animals loaded with cholesterol. This was accompanied by significantly faster plasma clearance of $\left[{ }^{3} \mathrm{H}\right]$. Since the uptake of $\left[{ }^{3} \mathrm{H}\right]$ cholesteryl ester by the liver in animals injected with ${ }^{14} \mathrm{C} /\left[{ }^{3} \mathrm{H}\right]$ acetyl LDL was significantly higher than that in animals injected with ${ }^{14} \mathrm{C} /\left[{ }^{3} \mathrm{H}\right]$ native LDL, it may be assumed that the cholesterol-loading was successful. ${ }^{36,37}$ It is interesting to notice that this increased uptake of $\left[{ }^{3} \mathrm{H}\right]$ cholesteryl ester by the liver of animals overloaded with cholesterol was accompained by increased levels of ${ }^{14} \mathrm{C}$-alpha-tocopherol in the liver $(\mathrm{P}<0.01)$.

There were no significant differences in the recovery of either label between apoE-poor and apoE-rich subfractions of HDL when results are considered as a percentage of distribution of label between subfractions. However, when recalculated with values of radioactivity found in HDL, significantly higher levels of $\left[{ }^{3} \mathrm{H}\right]$ were detected in both subfractions of HDL for treated animals, while ${ }^{14} \mathrm{C}$ was increased in apoE-rich HDL of these cholesterol-loaded rabbits. This discrepancy may be due to two factors: first, the two groups of animals may be too small to provide significant differences when the calculations are performed as relative percentages. Secondly, or additionally, the levels of radioactivity recovered in HDL were very different in the two groups of rabbits due to the design of the experiment. Therefore, only when considering the total recovery of ${ }^{14} \mathrm{C}$ and $\left[{ }^{3} \mathrm{H}\right]$ in HDL as counts per minute (cpm) or disintegrations per minute (dpm) do the previously apparent differences become significant.

It may be argued that, due to the high uptake of $\left[{ }^{3} \mathrm{H}\right]$ cholesteryl ester by the liver cells, the HDL system was not involved in removing cholesterol from endothelial cells. However, liver uptake of ${ }^{14} \mathrm{C} /\left[{ }^{3} \mathrm{H}\right]$ acetyl LDL is

\section{REFERENCES}

1. Miller NE. Raising high density lipoprotein. The clinical implications of recent studies. Biochem Pharmacol 1990;40:403-10. virtually restricted to the endothelial cells $\mathrm{s}^{36,37}$ and, to a great extent, dependent on HDL for transfer of cholesterol to hepatocytes. Uptake of modified LDL by Kupffer cells, which may be less dependent on HDL for further clearance, pertains to oxidized LDL rather than acetylated LDL. ${ }^{38}$ Furthermore, previous studies have shown a role for very specific subfractions of HDL in transporting labeled cholesterol in plasma of rabbits injected with $\left[{ }^{3} \mathrm{H}\right]$ acetyl LDL. ${ }^{22,23}$ Levels of both labels were significantly higher in apoE-rich HDL particles of animals injected with ${ }^{14} \mathrm{C} /$ $\left[{ }^{3} \mathrm{H}\right]$ acetyl LDL in comparison to those of animals injected with ${ }^{14} \mathrm{C} /\left[{ }^{3} \mathrm{H}\right]$ native LDL. The group of rabbits injected with native LDL will control for any plasma transfer of the labels among the lipoprotein subclasses. Any excess of ${ }^{14} \mathrm{C}$-alpha-tocopherol in HDL or in a subfraction of HDL in the cholesterol-loaded animals supports the notion of alpha-tocopherol transport away from peripheral tissues.

The present data are therefore indicative of an operative mechanism of reverse alpha-tocopherol transport, by which tissue alpha-tocopherol may be transported to the liver via HDL, as suggested by Kayden $\&$ Traber. ${ }^{7}$ It has been reported that alpha-tocopherol may be removed from storage tissues such as adipose tissue in situations of low plasma levels of alpha-tocopherol. ${ }^{7}$ Advanced human atherosclerotic plaques contain relatively high levels of alpha-tocopherol ${ }^{39}$ and the degree of its accumulation in the arterial wall may depend on active removal by HDL. The present report adds the evidence of alpha-tocopherol being removed from tissues during acute cholesterol loading in rabbits.

We have previously observed a strong positive association between the alpha-tocopherol content of apoErich HDL and plasma HDL levels. ${ }^{19}$ This finding, when taken together with the present results, points to a role for apoE-rich HDL particles enriched with alpha-tocopherol as a marker for individuals protected against atherosclerosis, possibly due to an efficient mechanism of "reverse cholesterol/alpha-tocopherol transport". Much more has to be learned of the role of antioxidants in the protection against atherosclerosis. ${ }^{40}$ Whether the purpose of "reverse alpha-tocopherol transport" is to protect cholesterol from oxidation during reverse cholesterol transport, or whether such an association is merely incidental, remains to be clarified.

2. Glomset JA. The plasma lecithin: cholesterol acyltransferase reactions. J Lipid Res 1968;9:155-67.

3. Barter PJ. High density lipoprotein and reverse cholesterol transport. Curr Opin Lipidol 1993;4:210-7.

4. Johansson J, Carlson LA, Landou C, Hamsten A. High density lipoprotein and coronary atherosclerosis. Arterioscl Thromb 1991;11:174-82. 
5. Williams PT, Krauss RM, Vranizan KM, Stefanick ML, Wood P1DS, Lindgren FT. Familial correlations of HDL subclasses based on gradient gel electrophoresis. Arterioscl Thromb 1992;12:1467-74.

6. Wilson HM, Patel JC, Russell D, Skinner ER. Alterations in the concentration of an apolipoprotein-E containing subfraction of high density lipoprotein in coronary heart disease. Clin Chim Acta 1993;220:175-87.

7. Kayden HJ, Traber MG. Absorption, lipoprotein transport, and regulation of plasma concentrations of vitamin $\mathrm{E}$ in humans. J Lipid Res 1993;34:343-58.

8. Parthasarathy S, Rankin SM. Role of oxidised low density lipoprotein in atherogensesis. Prog Lipid Res 1992;31:127-43.

9. Carpenter KL, van-den-Veer C, Taylor SE, Hardwick SJ, Clare K, Hegyi L, Mitchinson MJ. Macrophages, lipid oxidation, ceroid accumulation and alpha-tocoperol depletion in human atherosclerotic lesions. Gerontology 1995;41:53-67.

10. Ozer NK, Boscoboinik D, Azzi A. New roles of high density lipoprotein and vitamin $\mathrm{E}$ in the pathogenesis of atherosclerosis. Biochem Mol Biol Int 1995;35:117-24.

11. Sun J, Giraud DW, Moxley KA, Driskell JA. Beta-carotene and alpha-tocopherol inhibit the development of atherosclerotic lesions in hypercholesterolemic rabbits. Int J Vitamin Nutr Res 1997;67:155-63.

12. Salonen R, Seppanen K, Rauramaa R, Sepanen JT. Prevalence of carotid atheorsclerosis and serum cholesterol levels in eastern Finland. Atherosclerosis 1988;70:155-60.

13. Riemersma RA, Oliver M, Elton RA, Afthan G, Vartiainen E, Salo M, Rubba P, Mancini M, Georgi H, Vuilleumier JP, Gey KF. Plasma antioxidants and coronary heart disease: vitamins $\mathrm{C}$ and $\mathrm{E}$, and selenium. Eur J Clin Nutr 1990;44:143-50.

14. Gey FK, Puska P, Jordan P, Moser UK. Inverse correlation between plasma vitamin $\mathrm{E}$ and mortality from ischemic heart disease in cross-cultural epidemiology. Am J Clin Nutr 1991;53:326S-34S.

15. Riemersma RA, Wood DA, MacIntyre CCA, Elton RA, Gey $\mathrm{KF}$, Oliver MF. Antioxidants and pro-oxidants in coronary heart disease. Lancet 1991;337:432-3.

16. Hense HW, Stender M, Bors W, Keil U. Lack of association between serum vitamin $\mathrm{E}$ and miocardial infarction in a population with high vitamin E levels. Atherosclerosis 1993;103:21-8.

17. Street DA, Comstock GW, Salkeld RM, Schuep W, Klag MJ. Serum antioxidants and myocardial infraction: are low levels of carotenoids and alpha-tocopherol risk factors for myocardial infarction? Circulation 1994;90:1154-6.

18. Ohrvall M, Berglund L, Salminen I, Lithell H, Aro A, Vessby B. The serum cholesterol ester fatty acid composition but not the serum concentration of alpha-tocopherol predicts the development of myocardial infarction in 50 year old men. Atherosclerosis 1996;127:65-71.

19. Brown AJ, Fragoso YD. Alpha-tocopherols and carotenes are differently distributed in subfractions of high density lipoprotein. Biochim Biophys Acta 1994;1210:373-6.
20. Skinner ER. High density lipoprotein subspecies. Curr Opin Lipidol 1994;5:241-7.

21. Chapman JM. Animal lipoproteins: chemistry, structure and comparative aspects. J Lipid Res 1980;21:789-853.

22. Fragoso YD, Skinner ER. The role of subfractions of high density lipoprotein in the in vivo transport of cholesterol from cholesterol loaded hepatic and peripheral endothelial cells in the New Zealand White rabbit. Comp Biochem Physiol 1993;105B:699-706.

23. Fragoso YD, Skinner ER. Cholesterol loading of peripheral tissues alters the interconversion of high density lipoprotein subfractions in rabbits. Int J Cell Biol 1996;28:151-63.

24. Fragoso YD, Skinner ER. The effect of gammalinolenic acid on the subfractions of high density lipoprotein of the rabbit. Biochem Pharmacol 1992;44:1085-90.

25. Hay C, Rooke JA, Skinner ER. Fractionation of rat HDL by affinity chromatography: effect of prolonged ultracentrifugation on HDL subspecies. FEBS Lett 1978;91:30-3.

26. Weisgraber KH, Mahley RW. Subfractionation of human high density lipoprotein by heparin-Sepharose affinity chromatography. J Lipid Res 1980;21:316-25.

27. Griffin BA, Skinner ER, Maughan RJ. Plasma high density lipoprotein subfractions in subjects with different coronary risk indices as assessed by plasma protein concentrations. Atherosclerosis 1988;70:165-9.

28. Basu SK, Goldstein JL, Anderson RGW, Brown, MS. Degradation of cathionised low density lipoprotein and regulation of cholesterol metabolism in homozygous familial hypercholesterolemia. Proc Natl Acad Sci (USA) 1976;73:3178-82.

29. Klimov AN, Kozhemyakin LA, Pleskov VM, Andreeva LI. Antioxidant effect of high density lipoprotein in the peroxidation of low density lipoprotein. Byull Eksp Biol Med 1987;103:550-2.

30. Mackness MI, Arrol A, Durrington PN. Paraoxonase prevents accumulation of lipoperoxides in low density lipoprotein. FEBS Lett 1991;286: 152-4.

31. Mackness MI, Abbot C, Arrol A, Durrington PN. The role of high density lipoprotein and lipid soluble antioxidant vitamin in inhibiting low density lipoprotein oxidation. Biochem J 1993;294:829-34.

32. Gocke N, Frei B. Basic research in antioxidant inhibition of steps in atherosclerosis. J Cardiovasc Risk 1996;3:352-7.

33. Maseri A. Inflammation, atherosclerosis and ischemic event - exploring the hidden side of the moon. N Engl J Med 1997;336:1014-6.

34. Diaz MN, Frei B, Vita JA, Keaney JF. Antioxidants and atherosclerotic heart disease. N Engl J Med 1997;337:408-16.

35. Traber MG, Ramakrishnan R, Kayden HJ. Human plasma vitamin $\mathrm{E}$ kinetics demonstrates rapid recycling of plasma RRR-alpha-tocopherol. Proc Natl Acad Sci USA 1994;91:10005-8.

36. Nagelkerke JF, Barto KP, Van Berkel TJ. In vivo and in vitro uptake and degradation of acetylated low density lipoprotein by rat liver endothelial, Kupffer, and parenchimal cells. J Biol Chem 1983; 258:12221-7. 
37. Blomhoff R, Drevon CA, Eskild W, Helgerud P, Norum KR, Berg T. Clearance of acetyl low density lipoprotein by rat endothelial cells. J Biol Chem 1984;259:8898-903.

38. Van Berkel TJC, De Rijke YB, Kruijt JK. Saturable high affinity binding, uptake and degradation of rat plasma lipoproteins by isolated parenchymal and non-parenchymal cells from rat liver. J Biol Chem 1981;226:2282-9.

39. Suarna C, Dean RT, May J, Stocker R. Human atherosclerotic plaque contains both oxidised lipids and relatively large amounts of alpha-tocopherol and ascorbate. Arterioscler Thromb Vasc Biol 1995;15:1616-24.

40. Olsson AG, Yuan XM. Antioxidants in the prevention of atherosclerosis. Curr Opin Lipidol 1996;7:374-80.

\section{ACKNOWLEDGEMENTS}

This work was part of a Doctoral Thesis funded by The Wellcome Trust.

The author wishes to thank Dr. N. Flück, from Hoffmann-La Roche, Switzerland, for the generous gift of alpha-tocopherol- ${ }^{14} \mathrm{C}$-acetate. Thanks are due to $\mathrm{Dr}$ E. Roy Skinner from the University of Aberdeen, for useful discussion. The technical assistance of Mr. S. McBain in caring for the animals is gratefully acknowledged.

\section{ReSUMO}

Objetivo: investigar o transporte de alfa-tocoferol em lipoproteinas de coelhos sob dieta normal e durante sobrecarga de colesterol. Desenho: Dois coelhos brancos da Nova Zelândia receberam ${ }^{14} \mathrm{C}$-alfa-tocoferol na forma de acetato em dose oral única e a recuperação de radioatividade nas lipoproteínas e plasma foi monitorizada. Lipoproteína de baixa densidade (LDL) destes animais foi obtida e marcada com $\left[{ }^{3} \mathrm{H}\right]$ ester de colesterol. Três outros coelhos receberam injeções desta LDL duplamente marcada na forma nativa, enquanto mais três animais receberam injeções desta LDL na forma acetilada. Resultados: Queda dos níveis de ${ }^{14} \mathrm{C}\left[{ }^{3} \mathrm{H}\right]$ no plasma, captação hepática e níveis de radioatividade foram significativamente maior nos coelhos que receberam a forma acetilada de LDL. Partículas grandes de HDL, ricas em apolipoproteína E (apoE), continham níveis elevados de ambos os marcadores radioativos em coelhos que receberam injeção de acetil-LDL. Conclusão: Estes resultados sugerem a presença de mecanismos in vivo para o transporte reverso de alfa-tocoferol, análogo ao transporte reverso de colesterol. 